\title{
Stakeholder Analysis in Tourism Development of the Bintan Regency during the COVID-19 Pandemic
}

\author{
Mahadiansar ${ }^{1}$, Andy Fefta Wijaya ${ }^{2}$, Alfi Haris Wanto ${ }^{3}$ \\ 1,2,3 Public Administration Post Graduate Study Program, Faculty of Administration Science. Universitas Brawijaya, Jl. MT \\ Haryono No 169 Malang City, East Java 65141, Indonesia \\ Corresponding Author: mahadiansar@student.ub.ac.id \\ doi) https://doi.org/10.18196/jgpp.v8i3.11758 \\ Article Info
}

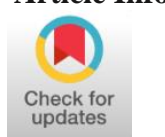

Article History;

Received:

2021-05-15

Revised:

2021-07-26

Accepted:

2021-09-04

\begin{abstract}
In improving the welfare of the people in border areas, the development of the tourism sector influences long-term economic growth, which has been the largest regional income source in Bintan Regency. The importance of interaction and stakeholder actors involved in tourism activities during the COVID-19 pandemic. This study aims to analyze the condition of stakeholder actors in tourism management in the Bintan Regency. The research method used a qualitative approach with stakeholder analysis using NVivo 12 with data collection techniques in interviews with stakeholders and existing secondary data, which was carried out in-depth analysis. The results showed three components (who, when, and how) with a significant correlation between stakeholders in tourism development in Bintan Regency, which was the local government that regulated the executive management as a facilitator. Then, community groups actively supported the development of travel bubble-based tourism in the country's border region. The private sector maintained and regulated health protocols to avoid the spread of COVID-19. Furthermore, the alternative is to improve stakeholder relations to approach harmonious communication between stakeholders in the tourism sector in the Bintan Regency.
\end{abstract}

Keyword: Stakeholder Analysis; Tourism; Bintan Regency; COVID-19.

\section{INTRODUCTION}

The tourism industry in developing countries depends on generating a source of state income to improve the community's welfare by empowering the potential of natural resources that the community at the regional level can manage. The development of human resources and the tourism industry is one of the keys to institutional development. Various forms of human resource development aim to increase awareness to strengthen the tourism sector's economy quickly. The increase in tourist visits both domestically and abroad, the higher the creation of community empowerment so that the creation of jobs so that the market competitiveness of the tourism industry has a sustainable economic guarantee.

However, since 2019, the condition of tourism at the international and national levels to the regions has experienced a drastic decline due to the spread of the COVID-19 pandemic, which has an impact on stakeholders in the policy strategy of the entire tourism sector in Indonesia (Asmoro et al., 2020; Djausal et al., 2020; Harirah \& Rizaldi, 2020; Silalahi \& Ginting, 2020; Sugihamretha, 2020 ), not only in the tourism industry sector but in various other sectors (Dalimunthe et al., 2020) The tourism industry in Indonesia has experienced a significant decline seen from the level of foreign tourist visits. In 2020, the tourism sector declined to $74.84 \%$, causing the Indonesian government to look for strategies to revive the tourism sector amidst the COVID-19 pandemic while still implementing health protocols according to WHO standards. The need for collaborative 
efforts between the central and local governments can strengthen tourism by involving all existing stakeholders ranging from tourism activists to local communities. (Dinarto et al., 2020)

Based on Law Number 10 of 2009 concerning Tourism, tourism development is based on benefit, kinship, fairness and equality, balance, independence, sustainability, participatory, sustainable, democratic, equality and unity. Furthermore, this principle is also for the realization by implementing a tourism development plan by considering the diversity, uniqueness, and uniqueness of culture and nature and human needs for tourism. Bintan Regency has strategic tourism potential, with direct borders to neighboring countries such as Singapore and Malaysia, so the number of tourist visits, both domestic and foreign tourists, is the main contributor to Regional Original Income (PAD) from the tourism sector. Based on data from the Central Statistics Agency (BPS) of the Bintan Regency, the increase in the number of tourists in 2016 was 305,404 people, then in 2017, the number of visitors was 368,592 people, and in 2019 the number was 522,399 people (Iswanto, 2019)

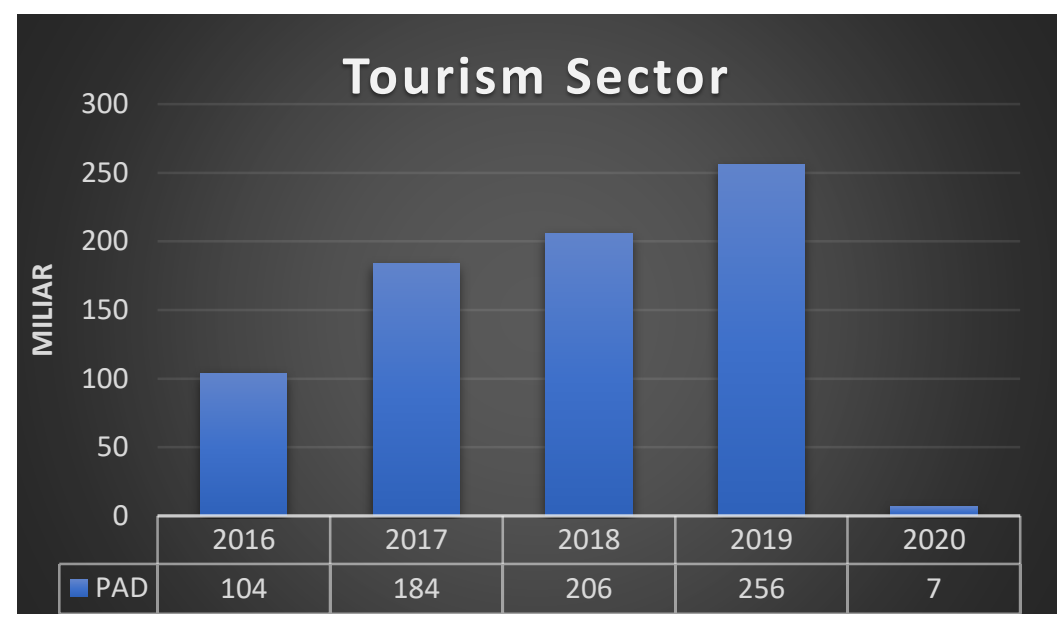

Figure 1. Local Own Revenue in the Tourism Sector of Bintan Regency 2016-2020 Source: Bintan Regency Central Bureau of Statistics, 2020

Based on figure 1, from year to year, the tourism sector continues to experience growth in Bintan Regency, making the people of Bintan Regency in their daily activities always face tourism both as tourism actors and participation in the tourism sector. However, the impact of the COVID19 pandemic in 2020, based on the graph above, the Regional Original Income (PAD) in the tourism sector has decreased by up to $98 \%$, which increases significantly in the previous year. Regarding Regional Regulation Number 5 of 2016 concerning RPJMD Bintan Regency 2016-2021, one of the points is the coordination of synchronization of development in the tourism sector or all stakeholders in the Bintan Regency. In addition, the results of observations made by researchers that stakeholders in the tourism sector in the Bintan Regency have experienced problems including reducing cooperation such as sports-based tourism activities or what is called Sport Tourism, environment-based tourism or what is called eco-tourism and travel-based tourism or what is called bubble tourism. 


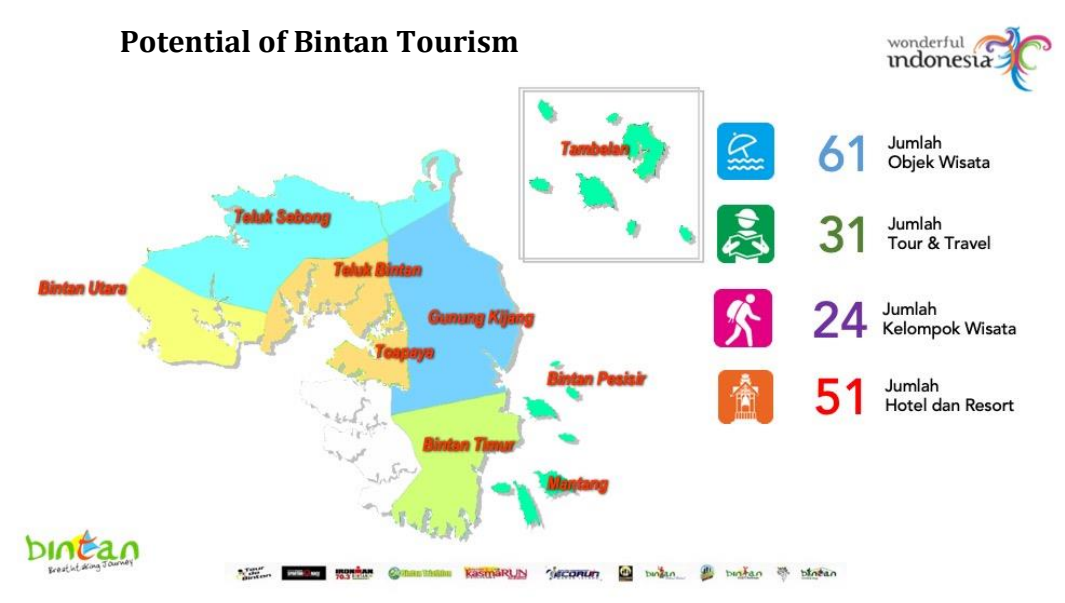

Figure 2. Current tourism potential in Bintan Regency

Source: Bintan Regency Tourism Culture Office, https://bintantourism.com/

Figure 2. shows that An emergency condition is that several stakeholders from the private industrial sector, local government, and tourism activists are walking respectively, because during the COVID-19 pandemic, tourism in Bintan Regency, the majority of visits from foreign countries, are prohibited from entering Indonesia. The role of stakeholders in Bintan Regency should be able to become a benchmark in abnormal conditions that can provide a structured contribution because the people of Bintan Regency certainly want certainty on their welfare where tourism has become their source of income in the last ten years (Larasati, 2020; Marina, 2012; Oktaviana et al., 2021), then researchers have concentrated on analyzing stakeholders who should act quickly in handling in maintaining the tourism sector while maintaining health protocols to prevent the spread of the COVID-19 pandemic.

Stakeholder analysis is oriented towards poor cooperation arrangements for the responsibilities of each organization that he leads. The purpose of the stakeholder analysis is not solely to improve the existing system, but rather the organizational needs that stakeholders need to maintain public trust so that they have a place that has a positive impact on the sustainability of the tourism sector and can provide national legitimacy by tourism stakeholders in Bintan Regency. The term stakeholder is a group or individual whose support is necessary for the welfare and survival of the organization. Stakeholders are individuals, organizations, or groups interested in certain natural and human resources (Brown \& Duguid, 2001).

Then according to (Maguire et al., 2012) describes as many as three important indicators as a stakeholder analysis tool consisting of stages (1) Who? Identify who should be involved who is the top priority in the subject to be researched; Stage (2) When? Determine when their organization/group should be involved according to the needs of the existing environment; Stage (3) How? Determine how they should be involved in positioning stakeholders in the objects. Previous research on stakeholder analysis is an activity of individuals or groups that are actively involved in activities influenced by the positives and negatives of the results of a collaboration that leads to organizational development both physically and non-physically in the tourism sector(Hidayah et al., 2019). Many stakeholders regulate the function of a management approach in social life in terms of human resource management from both public and private stakeholders (Brucker et al., 2013; Lienert et al., 2013; Mok et al., 2015; Srinivasan \& Dhivya, 2020). Stakeholder analysis also evaluates past policy decisions that will later enter the planning process in the future (Bouzon et al., 2018; Heravi et al., 2015). 


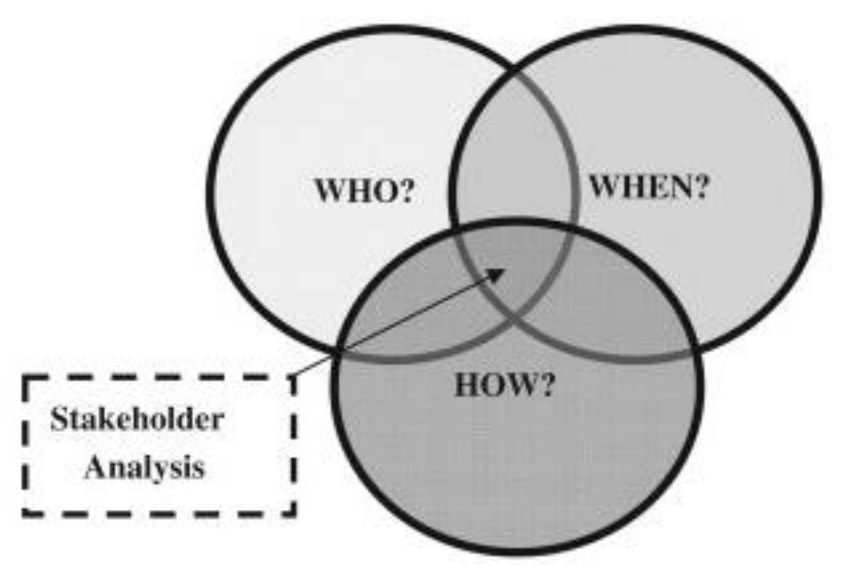

Figure 3. Indicators for stakeholder analysis

Source: Maguire (2012)

Based on the Figure 3. that's stakeholder involvement has many benefits for the quality of sustainability, which will impact society (Silberberg \& Martinez, 2019), which aims to provide solutions to a problem to generate hope in the system (Kelanti et al., 2015; Wood et al., 2021). Currently, the situation of stakeholders is very much a discussion of collaboration problems, and the condition of the value of the decisions made does not give satisfaction to joint decisions as stakeholder negotiations (Ramírez, 1999). Stakeholder analysis is an approach to understanding, improving, and supporting the system (Sentanu \& Kumalasari, 2020) and interacting with changes between organizations and groups. Identifying stakeholders will certainly have an impact in the form of cause and effect if stakeholders weaken with the COVID-19 pandemic conditions. Therefore, there is a need for stakeholder analysis of the Bintan Regency tourism sector.

However, previous research on stakeholder analysis only focused on the communication aspect, coordination aspect and cooperation aspect in the management of tourism in the involvement that has an important role (Raharjana et al., 2019). Then, the analysis of stakeholders in the tourism sector must strengthen cooperative relations such as coordinating, networking, good collaboration between stakeholders, thereby avoiding conflicts of interest and making it easier to determine who should be involved with existing developments and who needs improvement so that development becomes easier to implement in the tourism sector (Putri \& Santoso, 2020). Thus, effective communication, good cooperation with stakeholders, and an attitude of openness are identified as important prerequisites for developing synergistic interactions between stakeholders (Heslinga et al., 2019; Serravalle et al., 2019).

The stakeholder actors include local government, tourism industry, and tourism activist groups whose researchers focus on a strategic effort of stakeholders in making decisions by looking at current stakeholder analysis indicators. Hence, the analysis of tourism sector stakeholders can be efficient, transparent, and well legitimized by the community in contributing to the tourism sector in Bintan Regency. Therefore, the main purpose of this study is to analyze the tourism stakeholders of the Bintan Regency to anticipate mistakes in cooperation as a sustainable public interest process hoping to boost tourism development optimally with the new normal. The main reason for choosing the first research in Bintan Regency is that it has great potential to save the tourism sector during the COVID-19 pandemic because the strategic area borders neighboring countries such as Singapore and Malaysia. The second is the implementation of health protocols that are more prepared in the Bintan Regency than in Bali. Thirdly, tourism in Bintan Regency has a bigger event in collaboration with the international community. The problem formulation focuses on stakeholders who have contributed to strengthening sustainable tourism development during the COVID-19 pandemic in the Bintan Regency. 


\section{RESEARCH METHOD}

The research method used was qualitative as a research procedure that results in descriptive data resulting from secondary data and written and oral primer data from human behavior that can be logically observed (Maher, 2001; Moleong, 2012). Qualitative research raises fundamentals that depend on human observations from several case studies in in-depth testing of certain events intensively, and in detail, it emphasizes the characteristics of an object (Creswell, 2016). The types of data used in this study were primary data and secondary data. Primary data is obtained through written questions using a questionnaire or oral using the interview method. Meanwhile, secondary data is support obtained from relevant sources, usually in taking documents, reports, or data, and other supporting material and information in research (Galvan \& Galvan, 2017; Zed, 2014). Then, the analysis is carried out in-depth based on stakeholder analysis indicators (Maguire et al., 2012)

The researcher's data analysis used three persuasive approaches: matching the activity patterns of stakeholders in Bintan Regency, then developing explanations on tourism development carried out by stakeholders by looking at stakeholder indicators. The analytical emphasis also focuses on logical models in which the model matches empirically observed events with theoretically predicted events. The stakeholder analysis was prioritized from 3 indicators (who, when, and how) then assisted by using NVivo12 analysis software to see the correlation between stakeholder actors. Furthermore, the data analysis referred to secondary and primary data aims as an analytical strategy that focuses on case studies studied comprehensively (Yin, 2018). Stakeholder Analysis is a technique used to identify and assess the influence and importance of key actors, either within groups or organizations, that can significantly influence the success of activities or the realization of tourism activities in existing case studies.

\section{RESULT AND DICUSSION}

Stakeholder analysis must prioritize their involvement and role to strengthen tourism development in the conditions of the COVID-19 pandemic in the Bintan Regency. Stakeholder involvement is part of a series or analysis process that can be thoroughly examined in-depth. However, the stages in the stakeholder analysis must prioritize a clear interpretation according to current conditions that lead to the object of analysis indicators. Indicators in question can be explained as follows:

\section{Who; Tourism Stakeholder Actor?}

Stakeholder analysis should prioritize the actors involved who influence each other's magnitude or low relationship in their role as a form of participation in developing sustainable tourism in the Bintan Regency. The researchers used NVivo 12 software to map the results of interviews with several actors who had been interviewed using Jaccard's Cluster Analysis method. The results obtained by the 10 clusters that researchers obtained for the 12 actors involved can be seen in Table 2.

The discussion of indicators of power was carried out on the concept of stakeholders of actors involved in decision-making, including the role of each stakeholder in developing sustainable tourism in Bintan. Based on the results of the cluster analysis, the three strongest relationships between actors are shown by the highest Jaccard correlation value in Table 2 , which is between entrepreneurs $\leftrightarrow$ Culture and Tourism Office of Bintan Regency, then between entrepreneurs $\leftrightarrow$ Central Government, then Central Government $\leftrightarrow$ Culture and Tourism Office of Bintan Regency. The stakeholders of the three actors support each other with Jaccard's high efficiency based on interviews with each stakeholder in Bintan Regency. To strengthen the results of Jaccard's Cluster Analysis of 12 Actors, the researchers conducted mapping based on the results of interviews by displaying a chat hierarchy so that the determination of the characteristics of the interview results can be seen by stakeholder actors who have great 
potential in the development of sustainable tourism in Bintan Regency during the COVID-19 pandemic. The results of the chat hierarchy using NVivo12 software can be seen in figure 3 .

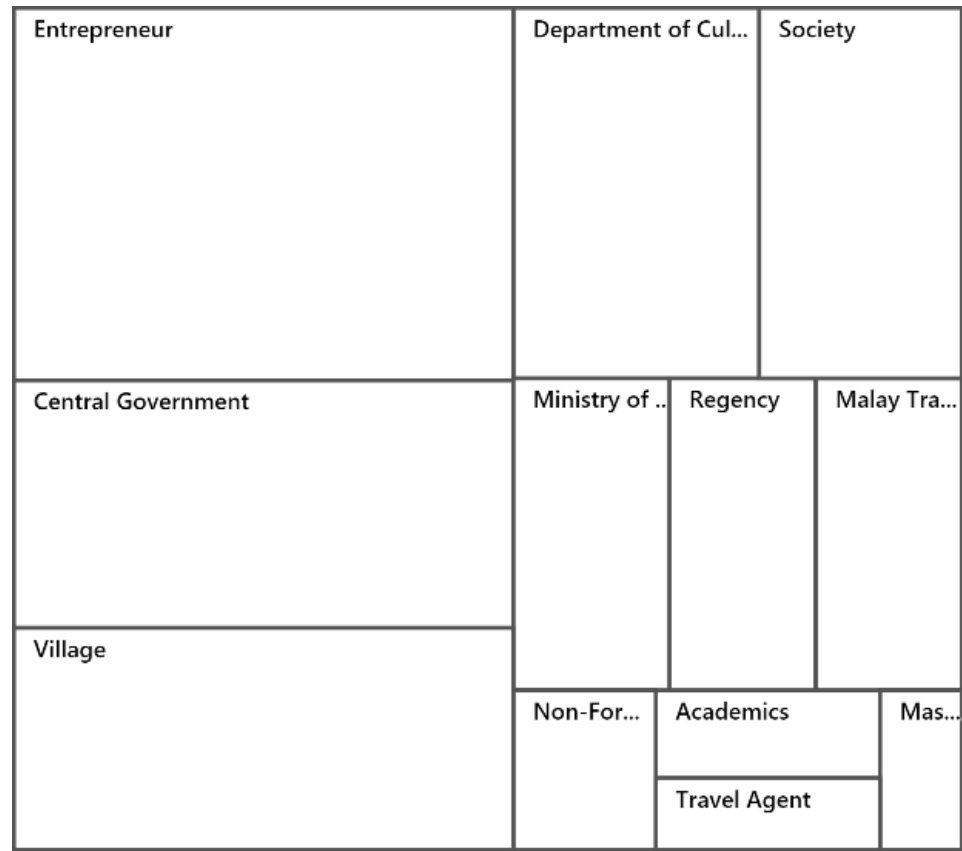

Figure 3. Chat Hierarchy of 12 Stakeholder Actors

Source: Processed by the researchers using NVivo 12

Based on figure 3. these results, the researcher has a description that entrepreneurs are the actors who have the most influence in the development of sustainable tourism. It can also be seen in the Wordclouds Overview obtained in the previous results that entrepreneurs are the most discussed actors based on six respondents who gave as many as 12 stakeholder actors. The Central Government and the BudPar Agency have the highest power level in sustainable tourism development with strong relationships with entrepreneurs. The discussion about actors in sustainable tourism development is sorted based on the chat hierarchy graph that identified 12 actors in Bintan Tourism Development.

\section{When; Knowledge Management and Tourism Stakeholder Information Exchange}

Knowledge management and information exchange are important elements of more effective stakeholder strengthening of each actor involved. On the one hand, knowledge management and information exchange are important components to build and maintain in a public service and policy decision. Each stakeholder will seek information from other stakeholders when there is a need to improve on focused activities that previously resulted in a lack of good cooperation between stakeholders within the organization. In developing sustainable tourism in the Bintan Regency during the COVID-19 pandemic, the researchers interviewed six respondents by coding according to stakeholder management according to the organization's performance area, leadings to when to act in tourism development Bintan Regency. The results of coding using NVivo12 software are explained in Table 3.

Based on the above results, the discussion of knowledge management indicators and information exchange is based on the researchers' interviews regarding knowledge management and information exchange between stakeholders. Through study research and sharing of ideas and inputs, knowledge management and network information exchange on tourism development in Bintan occurs with research studies conducted by academics. All existing stakeholders (Village Institutions, BUMdes, Entrepreneurs, Local Government, and Central Government) need to exchange information and knowledge to strengthen cooperation. Furthermore, the innovation in 
Simdes Prima is an application that is used in the exchange of information and knowledge between the village and the Ministry, which is also included in it, while the Village Office uses social media to carry out direct promotions to the community.

The importance of sustainable tourism in Bintan is the STD (Sustainable tourism Development) public facilities of Entrepreneurs, Government, Travel Agents, and Academics that knowledge management and information exchange on tourism development in Bintan occurs with the creation of the STD Forum, which is institutionally unregistered. However, the work results and contributions to the development of sustainable tourism are excellent. This STD forum can be a medium for exchanging information and knowledge for stakeholders to discuss the latest strategic issues regarding tourism development in pandemic conditions, implementing the CHSE, sharing ideas and input, and others. The need for tourism development to be developed by Penta-Helix (government, entrepreneurs, media, academics, society) all synergistic components all contribute to contribute shows that knowledge management and information exchange in tourism development in Bintan with the Penta-Helix concept developed by the Central Government in developing sustainable tourism. All components to synergize in this case regarding the focus of knowledge and information exchange.

\section{How; Participation of Relevant Tourism Stakeholders}

Participation between stakeholders greatly affects the relationship to social interaction in institutions to show the capacity to develop sustainable tourism in Bintan Regency during the COVID-19 pandemic. Participation in question is that it has a relevant relationship to the current phenomenon, based on the results of interviews by researchers with six stakeholder actors using NVivo 12 software which focuses on respondents' statements, the results of the Similarity NVivo12 coding can be seen in the figure 4 :

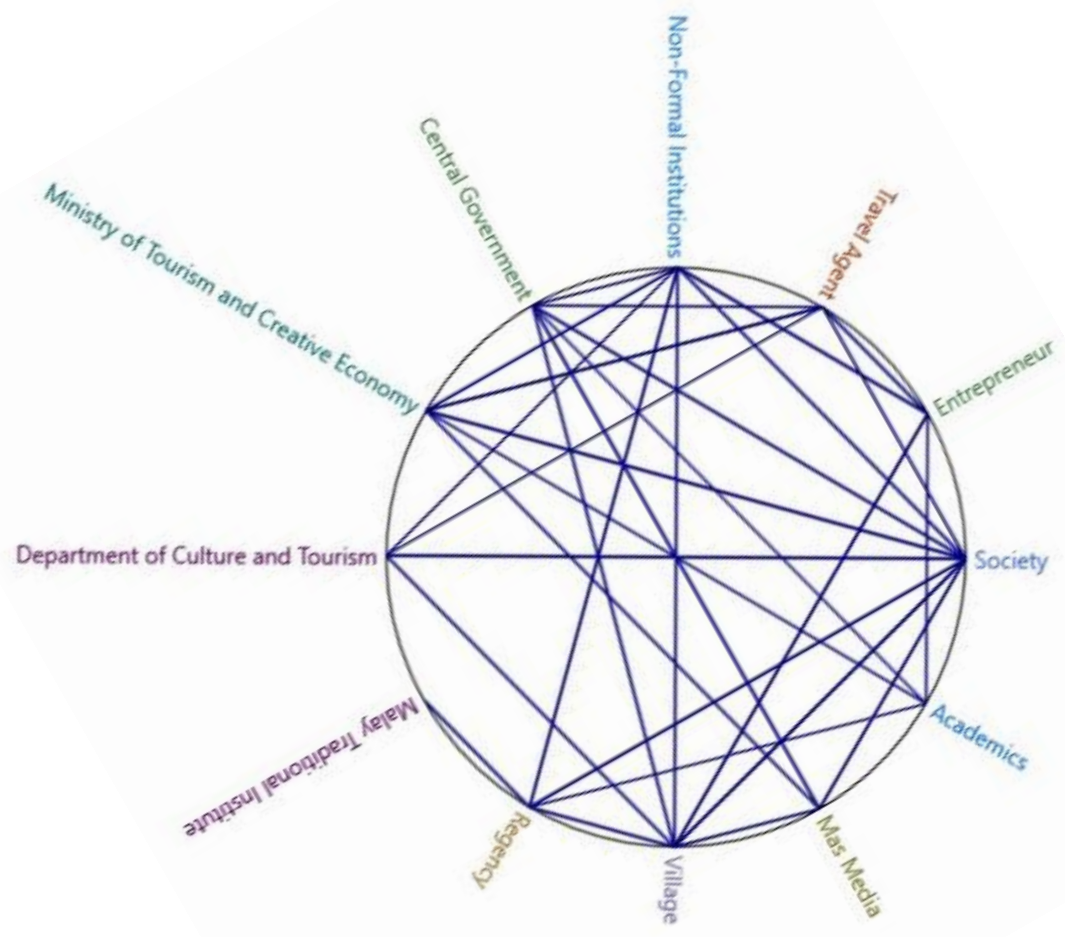

Figure 4. Participation in the Stakeholder Relationship Circle Source: Coding Similarity NVivo12 
Based on figure 4, no strong relationship between LAM and other actors is seen. The relationship between Circle of Stakeholders actors affects sustainable tourism development in Bintan Daerah because the cultural sector has no attraction. The existing culture is only a formality and has no selling value that can be used as cultural tourism in the development of tourism in the Bintan Regency. The researchers hope that cultural activities can be more collaboratively with tourism activities, while the discussion and explanation of the 12 actors in the stakeholder analysis in Coding Similarity NVivo12 based on the results of interviews with researchers can be described as follows:

\section{Entrepreneur}

Entrepreneurs are the most discussed actors based on interviews conducted by researchers. Entrepreneurs are the actors who feel the biggest impact due to the decline in the number of tourists in the Bintan Regency. Entrepreneurs are the actors most affected by the decline in the number of tourists in the Bintan Regency. Employers reduce the number of employees because activities in the resort area are owed. One of the efforts of resort managers in overcoming this problem is by opening resorts for domestic tourists.

\section{Central Government}

The Central Government has the highest level of power in the realm of tourism development in Bintan. Several rules and policies established during the COVID-19 pandemic directly or indirectly impacted tourism development in Bintan. Based on the results, there are 3 Central Government regulations that affect the tourism sector, namely: Regulation of the Minister of Law and Human Rights Number 11 of 2020 concerning the Prohibition of Foreigners from Entering the Territory of the Archipelago State of the Republic of Indonesia, Circular (SE) of the COVID-19 Task Force Number 12 of 2021 Regarding the Extension of Domestic Travel Provisions, and Guidelines for the Implementation of the Ministry of Tourism and Creative Economy policies in the form of CHSE implementation in the Tourism Industry which refers to the Decree of the Minister of Health of the Republic of Indonesia Number HK.01.07 / MENKES / 382/2020 Concerning Public Health Protocols in Places and Public Facilities in the Context of Prevention and Control of COVID-19.

\section{Society}

The community is an actor involved in the development of sustainable tourism. Under PerMenPar No. 14 of 2016, the main component must include economic use for local communities in developing sustainable tourism. Besides, the community is one of the dimensions of the PentaHelix conceptualized by the government. Some strategies used are approaching the Community Leader and conducting community empowerment by recruiting residents to work. More socialization is needed for the community to be more aware of tourism because the benefits of the tourism sector are very large for residents. Local people get great benefits from tourism activities. Tourists can purchase MSME products.

\section{Local Government}

Local and Central Government review the quarantine policy and negotiate with the country concerned regarding the planned Reciprocal Green Lane / Travel Corridor Arrangement (RGL / TCA), which will be implemented. The regency has a program before the COVID-19 pandemic to open new tourist spots, culinary spots, and other recreational places. The role of the Regency and Regional Government in the COVID-19 pandemic is to conduct socialization for the community to reduce the stigma of COVID-19 due to tourism activities. With the good implementation of the CHSE, the district and local governments should reduce the stigma of the community. The Bintan Regional Government receives Regional Original Income (PAD) which is dominated by the tourism sector. With the Governor and the Regent, Bintan tourism will be prioritized because the tourism sector dominates the PAD Bintan. In the state of the COVID-19 pandemic, Bintan immediately opened its borders to implement the Reciprocal Green Lane / Travel Corridor Arrangement (RGL / TCA) plan. The governor's efforts to reopen Bintan tourism to implement a Reciprocal Green Lane / Travel Corridor Arrangement (RGL / TCA), expected to start on April 21, 2021. However, unfortunately, this implementation is still postponed. The Singapore Government has yet to confirm when the Reciprocal Green will be carried out. Lane / Travel Corridor 
Arrangement (RGL / TCA) with the Government of Indonesia. The implementation of cooperation needs to be done in the development of sustainable tourism. For example, with the holding of the Tour de Bintan, all stakeholders provide roles and assistance for the event's sustainability.

\section{Department of Culture and Tourism}

The role of the Culture and Tourism Office is to guide and assist. The Culture and Tourism Office also has a role in direct relations with foreign investors. Some strategies carried out by the Culture and Tourism Office in increasing tourists are promoted through social media and mass media. Employees at the Culture and Tourism Office are also asked to carry out promotions on their social media. In addition, the strategy carried out by the Culture and Tourism Office makes it imperative for the official to travel to conduct a comparative study to stay in the Tourism Village. The Culture and Tourism Office is an institution that the Malay Customary Institution (LAM) highly hopes for because cooperation is always established. Communication, cooperation, and input sharing always occur between the Culture and Tourism Office and the Malay Customary Institution. It shows the close relationship between the Culture and Tourism Office and the Malay Customary Institution. The Culture and Tourism Office focuses Bintan tourism on sports tourism and does not prioritize Bintan culture in the tourism sector. Some of the reasons are because Bintan culture is not universal, and Bintan culture has no selling value. The efforts of the Culture and Tourism Office in promoting tourism in Bintan are by promoting via social media and cooperation with tourism-loving communities because the promotion costs are cheap. In addition, the Department of Culture and Tourism has a program in making pocket applications for tourists, but this has not yet been realized. Regarding community empowerment, the Culture and Tourism Office hopes that Entrepreneurs will involve the role of tourism with the Community (Tourism Village).

\section{The Ministry of Tourism and Creative Economy}

The Ministry of Tourism and Creative Economy focuses on standardizing the CHSE to restore the tourism sector during a pandemic. The role of KemenPareKraf in developing tourism in Ekang Anculai Village is one example. The Ministry of Tourism and Creative Economy provides good stimulation by publishing via social media and collaborating with Mass Media. Currently, Ekang Angulai is one of the tourism villages to be reckoned with in Indonesia. Therefore, the Ministry of Tourism and Creative Economy is expected to do more stimulation so that all Tourism Villages in Bintan can develop well, such as Desa Ekang Angulai. The Ministry of Tourism and Creative Economy implemented the Reciprocal Green Lane / Travel Corridor Arrangement (RGL / TCA). Wan hopes to implement the Reciprocal Green Lane / Travel Corridor Arrangement (RGL / TCA). In addition, the role of the Ministry of Tourism and Creative Economy is by conducting CHSE certification, training hotel employees on the CHSE, inviting and pressuring employers to conduct CHSEs, and evaluating the implementation of the CHSE in Business Places.

\section{Village}

The role of the village continues to encourage tourism even in this COVID-19 condition. Several collaborations were carried out before the COVID-19 condition between BUMdes, PKT, and Entrepreneurs. This activity is carried out so that entrepreneurs buy products from BUMdes and PKT. BUMdes assists in the form of Health Protocols for local Entrepreneurs. The village conducts direct promotions to the community through social media regarding tourist sites in Bintan regarding promotional activities. Entrepreneurs are expected to collaborate more with community-based tourism such as Tourism Village. Later, tourists will also visit the Tourism Village's which is managed by the community, not only staying in the Resort area so that local community empowerment occurs. Through the Village Government, the Bintan Regency Government will collect data on local tourism and report to the KemenPareKraf to stimulate the Tourism Villages in Bintan. Examples are Sri Bintan Village and Lancang Kuning Village.

\section{Academics}

Academics are actors who influence sustainable tourism development following the Regulation of the Minister of Tourism of the Republic of Indonesia No. 14 of 2016. Academics are one of the most important actors. The input of ideas from academics is very good in developing 
sustainable tourism in Bintan through research and studies on sustainable tourism development. Academics have a role in finding solutions in promoting tourism. Collaboration that can be done with academics, for example, is by making pocket applications for tourists. In addition, academics provide ideas in the form of tourism innovation in making applications in designing pocket applications for tourists. In addition, academics are needed in implementing the Penta-Helix conceptualized by the government.

\section{Travel Agent}

Travel Agent is one of the actors in developing sustainable tourism because Travel Agents have a direct relationship with tourists and the tour plans. Travel Agents are huge because they make vacation packages for tourists. It especially considers the empowerment of local communities by collaborating with local businesses in a lunch package that buys fish from local fishers. The hope is that the purchasing rate will increase by making the packages collaborated with community businesses.

\section{Mass Media}

Mass media in the development of sustainable tourism is by reporting about tourist attractions in Bintan. Before COVID-19, Entrepreneurs usually carry out their promotions. Usually, entrepreneurs advertise through TV media in neighboring countries like Singapore because most tourists come from Singapore. However, in the condition of COVID-19, there are no more promotions carried out by entrepreneurs because the border is still closed.

\section{Non-Formal Institutions}

In the context of Non-Formal Institutions, several Non-Formal Institutions have been identified that have a role in developing sustainable tourism in Bintan, namely the PKK Group, The Youth Tourism Awareness Group (POKDARWIS), and Tourism Lovers Group. Several groups in the village are such as the PKK group that can collaborate with several stakeholders. In addition, there are groups of tourism activists and youth groups that promote tourist attractions in Bintan and can be a source of finding ideas for existing problems. Currently, there is more communication with tourism lovers associations to promote tourist attractions in Bintan.

\section{Traditional Malay Institution}

The Malay Customary Institution (Lembaga Adat Melayu), an institution that becomes a forum for Malay culture in Bintan, is one of the actors involved in developing sustainable tourism in Bintan. Culture and tourism cannot be separated. However, not all tourism events in Bintan collaborate with cultural activities. Some of the problems that arise are the large number of cultural actors recruited from outside Bintan. It is due to Entrepreneurs choosing to recruit outsiders who can live in the hotel area and be ready to appear at any time.

Regarding promoting culture, LAM promotes cultural activities that are collaborated with tourism through the Cultural Tourism Office and the Regional Government. The amalgamation of culture, dance, and tourism was done before COVID. Now, there have been no cultural activities since the COVID-19 pandemic. The market for Bintan culture is still limited. Bintan culture has no selling value compared to Sports tourism in Bintan, seen in the absence of a strong relationship between LAM and other actors, as seen in the Circle Graph of Coding Results Relationship for 12 Actors. The researchers hope that cultural activities can collaborate more with tourism activities.

\section{CONCLUSION}

Stakeholder analysis on tourism activities carried out in the conditions of the COVID 19 pandemic must pay attention to a structured process on strengthening collaboration, but trust in stakeholders in efforts to prepare, implement and impact on the implementation of tourism management in Bintan Regency must be following the vision and mission of tourism both in regional, national and international levels with the adaptation of new habits. Stakeholder participation should create a conducive atmosphere for those responsible for the process without continuous participation. There will be obstacles on the priority scale of 3 component stakeholder indicators (who, when, and how) as they should be. 
Strengthening partnerships in the revival of tourism in Bintan Regency does not have a good correlation, shown in the strengthening of internal stakeholders in each institution due to the impact of the COVID-19 pandemic, be it the local government, the tourism industry and the tourism activist groups themselves. Stakeholder relations in the tourism sector in Bintan Regency must prioritize the principle of a win-win solution. First, stakeholders' new adaptation process in tourism development in Bintan Regency must involve the entire community to be fair and transparent, good tourism strategies for stakeholders. The main interest must be clear in mapping the potential. Thus, the tourism sector in Bintan Regency is legally recognized in an informal position.

\section{ACKNOWLEDGEMENT}

We want to express our gratitude to the managers of the Journal of Governance Public Policy in 2021, who have provided input on improving this manuscript to be published in volume 8 number 2 of 2021. Not to forget our thanks also stakeholders in the development of tourism in Bintan Regency, Kepulauan Riau Province, for providing information about tourism conditions during the COVID-19 pandemic.

\section{REFERENCE}

Asmoro, A. Y., Bachri, T. B., \& Detmuliati, A. (2020). New normal bagi pariwisata Bali di masa pandemi COVID 19. Pariwisata Budaya: Jurnal Ilmiah Pariwisata Agama Dan Budaya, 5(2), 57-65. https://doi.org/10.36275/mws

Bouzon, M., Govindan, K., \& Rodriguez, C. T. (2018). Evaluating barriers for reverse logistics implementation under a multiple stakeholders' perspective analysis using grey decisionmaking approach. Resources, Conservation and Recycling, 128, 315-335. https://doi.org/10.1016/j.resconrec.2016.11.022

Brown, J. S., \& Duguid, P. (2001). Knowledge and Organization: A Social-Practice Perspective. Organization Science, 12(2), 198-213. https://doi.org/10.1287/orsc.12.2.198.10116

Brucker, K. de, MacHaris, C., \& Verbeke, A. (2013). Multi-criteria analysis and the resolution of sustainable development dilemmas: A stakeholder management approach. European Journal of Operational Research, 224(1), 122-131. https://doi.org/10.1016/j.ejor.2012.02.021

Creswell, J. W. (2016). 30 essential skills for the qualitative researcher. Sage Publications.

Dalimunthe, D. Y., Valeriani, D., Hartini, F., \& Wardhani, R. S. (2020). The readiness of supporting infrastructure for tourism destination in achieving sustainable tourism development. Society, 8(1), 217-233. https://doi.org/10.33019/society.v8i1.149

Dinarto, D., Wanto, A., \& Sebastian, L. C. (2020). COVID-19: Impact on Bintan's Tourism Sector. S. Rajaratnam School of International Studies. www.rsis.edu.sg

Djausal, G. P., Larasati, A., \& Muflihah, L. (2020). Strategi pariwisata ekologis dalam tantangan masa pandemik COVID-19. Jurnal Perspektif Bisnis, 3(1), 57-61. https://doi.org/10.23960/jpb.v3i1.15

Galvan, J. L., \& Galvan, M. C. (2017). Writing literature reviews : A guide for student of the social and behavior sciences (7th ed.). Routledge.

Harirah, Z., \& Rizaldi, A. (2020). Merespon Nalar Kebijakan Negara Dalam Menangani Pandemi Covid 19 Di Indonesia. Jurnal Ekonomi Dan Kebijakan Publik Indonesia, 7(1), 36-53. https://doi.org/10.24815/ekapi.v7i1.17370 
Heravi, A., Coffey, V., \& Trigunarsyah, B. (2015). Evaluating the level of stakeholder involvement during the project planning processes of building projects. International Journal of Project Management, 33(5), 985-997. https://doi.org/10.1016/j.ijproman.2014.12.007

Heslinga, J., Groote, P., \& Vanclay, F. (2019). Strengthening governance processes to improve benefit-sharing from tourism in protected areas by using stakeholder analysis. Journal of Sustainable Tourism, 27(6), 773-787. https://doi.org/10.1080/09669582.2017.1408635

Hidayah, N. A., Hutagalung, S. S., \& Hermawan, D. (2019). Analisis peran stakeholder dalam pengembangan wisata talang air peninggalan kolonial Belanda di Kelurahan Pajaresuk Kabupaten Pringsewu. Publikaauma; Jurnal Administrasi Publik, 7(1), 55-71.

Iswanto, R. (2019). Badan Pusat Statistik Kabupaten Bintan. Badan Pusat Statistik Kabupaten Bintan. $\quad$ https://bintankab.bps.go.id/pressrelease/2019/08/01/179/perkembanganpariwisata-provinsi-kepulauan-riau-juni-2019.html

Kelanti, M., Hyysalo, J., Lehto, J., Saukkonen, S., Oivo, M., \& Kuvaja, P. (2015). Soft system stakeholder analysis methodology. International Conference on Software Engineering Advances (ICSEA), November, 122-130. https://www.thinkmind.org/index.php?view=article\&articleid=icsea_2015_5_40_10139

Larasati, R. (2020). Analisis hubungan potensi obyek wisata dan tingkat valuasi wisatawan pantai di Pulau Bintan Provinsi Kepulauan Riau. Electronic Theses and Disertastion.

Lienert, J., Schnetzer, F., \& Ingold, K. (2013). Stakeholder analysis combined with social network analysis provides fine-grained insights into water infrastructure planning processes. Journal of Environmental Management, 125, 134-148. https://doi.org/10.1016/j.jenvman.2013.03.052

Maguire, B., Potts, J., \& Fletcher, S. (2012). The role of stakeholders in the marine planning process-Stakeholder analysis within the Solent, United Kingdom. Marine Policy, 36(1), 246257. https://doi.org/10.1016/j.marpol.2011.05.012

Maher, M. (2001). Framing: An Emerging Paradigm or A Phase of Agenda Setting? In Framing Public Life: Perspectives on Media and Our Understanding of the Social World (pp. 83-94).

Marina, H. (2012). Ekonomi politik Pariwisata kawasan wisata lagoi Kabupaten Bintan. Jurnal Fakultas Ilmu Sosial Dan Ilmu Politik.

Mok, K. Y., Shen, G. Q., \& Yang, J. (2015). Stakeholder management studies in mega construction projects: A review and future directions. International Journal of Project Management, 33(2), 446-457. https://doi.org/10.1016/j.ijproman.2014.08.007

Moleong, L. J. (2012). Metodelogi penelitian kualitatif. Remaja Rosdakarya.

Oktaviana, R. F., Muhammad, A. S., Kurnianingsih, F., \& Mahadiansar, M. (2021). Internal condition analysis on tourism development of Bintan Regency 2019. Indonesian Journal of Tourism and Leisure, 2(1), 51-61. https://doi.org/10.36256/ijtl.v2i1.129

Putri, P. A. V. A., \& Santoso, E. B. (2020). Analisis pemangku kepentingan dalam pengembangan kawasan cagar budaya sebagai destinasi wisata Kota Pontianak. Jurnal Wilayah Dan Lingkungan, 8(3), 202-213. https://doi.org/10.14710/JWL.8.3.202-213

Raharjana, D. T., Putra, H. S. A., Wijono, D., \& Kusworo, H. A. (2019). Analisis pemangku kepentingan destinasi Pariwisata Dieng Plateau Jawa Tengah. Jurnal Hospitaliti Dan Pariwisata, 2(2), 15-31. https://doi.org/10.35729/JHP.V2I2.30

Ramírez, R. (1999). Stakeholder analysis and conflict management. In Virginia Tech. Virginia Tech. https://vtechworks.lib.vt.edu/handle/10919/65992

Sentanu, I. G. E. P. S., \& Kumalasari, K. (2020). Analisis kepentingan stakeholder dalam 
Pengelolaan UB Forest Berbasis hutan pendidikan untuk mendukung keberlanjutan sistem agroforestri. LIKHITAPRAJNA Jurnal Ilmiah, 22(2), 122-132.

Serravalle, F., Ferraris, A., Vrontis, D., Thrassou, A., \& Christofi, M. (2019). Augmented reality in the tourism industry: A multi-stakeholder analysis of museums. Tourism Management Perspectives, 32, 100549. https://doi.org/10.1016/J.TMP.2019.07.002

Silalahi, D. E., \& Ginting, R. R. (2020). Strategi kebijakan fiskal pemerintah Indonesia dalam menghadapi dampak pandemi COVID-19. Jesya (Jurnal Ekonomi \& Ekonomi Syariah), 3(2), 156-167. https://doi.org/10.36778/jesya.v3i2.193

Silberberg, Mina., \& Martinez, Viviana. (2019). Community and Stakeholder Engagement. Primary Care - Clinics in Office Practice, 46(4), 587-594. https://doi.org/10.1016/j.pop.2019.07.014

Srinivasan, N. P., \& Dhivya, S. (2020). An empirical study on stakeholder management in construction projects. Materials Today: Proceedings, 21(xxxx), 60-62. https://doi.org/10.1016/j.matpr.2019.05.361

Sugihamretha, I. D. G. (2020). Respon Kebijakan: Mitigasi Dampak Wabah Covid-19 Pada Sektor Pariwisata. Jurnal Perencanaan Pembangunan: The Indonesian Journal of Development Planning, 4(2), 191-206. https://doi.org/10.36574/jpp.v4i2.113

Wood, D. J., Mitchell, R. K., Agle, B. R., \& Bryan, L. M. (2021). Stakeholder identification and salience after 20 years: Progress, problems, and prospects. Business and Society, 60(1), 196-245. https://doi.org/10.1177/0007650318816522

Yin, R. K. (2018). Case study research and applications: Design and methods (Sixth). Sage Publications.

Zed, M. (2014). Metode penelitian kepustakaan (3rd ed.). Yayasan Obor Indonesia. 
Table 2. Results Jaccard's Cluster Analysis of 12 Actors

\begin{tabular}{|c|c|c|}
\hline Code A & Code B & $\begin{array}{l}\text { Coeffisient } \\
\text { Jaccard }\end{array}$ \\
\hline Entrepreneurs & Culture and Tourism Office & 0,542222 \\
\hline Entrepreneurs & Central Government & 0,538462 \\
\hline Central Government & Culture and Tourism Office & 0,418043 \\
\hline $\begin{array}{lll}\begin{array}{l}\text { Independent } \\
\text { (LAM) }\end{array} & \text { Accreditation } & \text { Agency } \\
\end{array}$ & Culture and Tourism Office & 0,384348 \\
\hline $\begin{array}{l}\text { Ministry of Tourism and Creative } \\
\text { Economy }\end{array}$ & Regency & 0,35865 \\
\hline Entrepreneurs & Culture and Tourism Office & 0,352113 \\
\hline Entrepreneurs & Community & 0,348786 \\
\hline Central Government & $\begin{array}{lll}\begin{array}{l}\text { Independent } \\
\text { (LAM) }\end{array} & \text { Accreditation } & \text { Agency } \\
\end{array}$ & 0,340314 \\
\hline Community & Village & 0,331288 \\
\hline Central Government & Regency & 0,32093 \\
\hline Community & Culture and Tourism Office & 0,314516 \\
\hline $\begin{array}{l}\text { Ministry of Tourism and Creative } \\
\text { Economy }\end{array}$ & Culture and Tourism Office & 0,306475 \\
\hline Central Government & $\begin{array}{l}\text { Ministry of Tourism and Creative } \\
\text { Economy }\end{array}$ & 0,299852 \\
\hline Community & Regency & 0,291139 \\
\hline Entrepreneurs & Regency & 0,288991 \\
\hline
\end{tabular}

Table 3. Results of Knowledge Management Coding and Stakeholder Information Exchange

\begin{tabular}{|c|c|c|}
\hline Respondent & Reference & Statement \\
\hline \multirow[t]{2}{*}{$\begin{array}{l}6 \text { Stakeholder } \\
\text { Respondents Based } \\
\text { on the results of } \\
\text { interviews with } \\
\text { researchers }\end{array}$} & 1 & $\begin{array}{l}\text { - Seribu Pinang Tourism Village, through community networks and } \\
\text { officials, is asked to help upload tourism potential through social } \\
\text { networking. } \\
\text { Communication remains established and is always asked for } \\
\text { opinion or input by the cultural and tourism office and } \\
\text { entrepreneurs in tourism. } \\
\text { They are afraid that COVID will spread in their area, but after the } \\
\text { arrival of the regent, governor, and health experts. After the } \\
\text { socialization, the community understood this. The hope is to keep } \\
\text { the borders open so that entrepreneurs can run their businesses } \\
\text { well again. } \\
\text { Sustainable tourism in Bintan is the STD (Sustainable Tourism } \\
\text { Development) forum. Entrepreneurs, government, travel agents, } \\
\text { and academics in the STD forum are not institutionally legal or } \\
\text { have not been registered with the Tourism Office. However, the } \\
\text { local government has recognized the forum and has produced } \\
\text { work meetings or work meetings on several occasions. There is a } \\
\text { contribution and needs to be taken into account from the forum to } \\
\text { the sustainability of tourism. Lagoi Managers / Entrepreneurs } \\
\text { facilitate such meetings, mostrecently at the Banyan Tree in } 2020 . \\
\text { Tourism development developed by Penta-Helix (government, } \\
\text { business people, media, academics, society) all synergistic } \\
\text { components contribute. There is a Hotel / Entrepreneur } \\
\text { association, a travel association. }\end{array}$ \\
\hline & 2 & $\begin{array}{l}\text { - Community Service is important in coloring HR personnel both in } \\
\text { the apparatus, through research studies. Input is very important } \\
\text { in harmonizing cooperation. Relationships with academic } \\
\text { practitioners are very important by sharing ideas and input. } \\
\text { The Malay Customary Institution (Lembaga Adat Melayu) } \\
\text { promotes activities made by LAM and activities in collaboration }\end{array}$ \\
\hline
\end{tabular}




\begin{tabular}{|c|c|c|}
\hline Respondent & Reference & Statement \\
\hline & & $\begin{array}{l}\text { with the Regional Government or the Department of Culture and } \\
\text { Tourism uploaded via WhatsApp, Social Media, Facebook (easily } \\
\text { accessed by various groups). } \\
\text { Expectations from the village to convince tourists to continue } \\
\text { carrying out tourism activities according to the prokes } \\
\text { regulations. With district socialization so that tourists feel safe to } \\
\text { carry out tourism activities. } \\
\text { The Bintan Regency Government will collect data on local tourism, } \\
\text { and it will be reported to the Ministry of Tourism and Creative } \\
\text { Economy of the Republic of Indonesia so that it can be stimulated. } \\
\text { Including several areas for DPUD (Regional Superior Tourism } \\
\text { Destinations), including the Village Sri Bintan, Sassy Kuning. } \\
\text { The Culture and Tourism Office uses online promotions } \\
\text { (Facebook, Twitter) and collaborates with tourism-loving } \\
\text { communities such as Generasi Pesona Indonesia (millennial } \\
\text { children who like to travel) because of the low promotional costs. }\end{array}$ \\
\hline & 3 & $\begin{array}{l}\text { - All lines must be strong, and cooperation must be actualized. All } \\
\text { parties play a role from the village, BUMdes business plan, village } \\
\text { stakeholders, tourism actors, district and national to work } \\
\text { together } \\
\text { The Department of Culture and Tourism and the Malay Customary } \\
\text { Institution will always cooperate, like it or not, love or not love, } \\
\text { and we must work together. } \\
\text { Communication issues were discussed with the Head of the Bintan } \\
\text { Culture and Tourism Office. By making applications/technology } \\
\text { for tourism information for the public and tourists regarding } \\
\text { tourism in Bintan, which contains information on hotels/places of } \\
\text { business, routes, retribution too. The follow-up to integrated } \\
\text { communications had not occurred at the time of the CovID-19 } \\
\text { outbreak. } \\
\text { Communicate more with communities such as travel associations, } \\
\text { hotel entrepreneurs associations, tourism lovers associations. }\end{array}$ \\
\hline & 4 & $\begin{array}{l}\text { - } \\
\text { - Need to strengthen the role of Penta-Helix. } \\
\text { CSR management in Bintan does not yet exist in Bintan. All } \\
\text { Entrepreneurs are expected to be combined with one institution } \\
\text { for the implementation of CSR. So it is not only Lagoi who does } \\
\text { CSR. All entrepreneurs will be involved in CSR. }\end{array}$ \\
\hline & 5 & $\begin{array}{l}\text { - Travel publications usually use social media such as Facebook, } \\
\text { Instagram, and Sistem Informasi Desa (Simdes Prima) in } \\
\text { collaboration with the Ministry. Ask for help in making news } \\
\text { related to tourism in Bintan so that people will fall in love with } \\
\text { publications, to encourage tourists to come to Bintan }\end{array}$ \\
\hline
\end{tabular}

